\title{
Preliminary assessment of heavy metals levels of soils of an oil field in the Niger Delta, Nigeria
}

\author{
${ }^{1 *}$ C. M. A. Iwegbue, ${ }^{2}$ F. E. Egobueze and ${ }^{3}$ K. Opuene \\ ${ }^{1}$ Department of Chemistry, Delta State University, Abraka, Nigeria. \\ ${ }^{2}$ Institute of Geosciences and Space Technology, Rivers State University of Science and Technology, Port Harcourt, Nigeria. \\ ${ }^{3}$ Department of Chemistry, University of Nigeria, Nsukka, Nigeria
}

Received 29 October 2005;

revised 8 March 2006;

accepted 15 March 2006;

available online 20 April 2006

ABSTRACT: This communication presents the results of preliminary investigation of the characteristic levels of heavy metals in surface soils of an oilfield in the Niger Delta. The results indicate higher concentration of the following metals: $\mathrm{Cd}, \mathrm{Pb}, \mathrm{Cu} ; \mathrm{Ni}, \mathrm{Zn}, \mathrm{Cr}, \mathrm{Mn}$ and $\mathrm{Hg}$ in soils around the gas plant than the pipeline areas. There is a significant temporal and spatial variation in the concentrations of the heavy metals. Samples collected during the wet season showed lower concentrations of heavy metals. The distribution pattern of heavy metals follows the following order $\mathrm{Fe}>\mathrm{Mn}>\mathrm{Zn}>\mathrm{V}>\mathrm{Cr}>\mathrm{Pb}>\mathrm{Cu}>\mathrm{Ni}>\mathrm{Cd}>\mathrm{Hg}>$ As. The soils around the oilfield could be considered unpolluted since the concentrations of the metals fit into background levels and concentrations found in natural and agricultural soils. Since metal build up is a gradual process, farmland, fishing ponds and water bodies closer to these facilities will be at risk of heavy metal pollution over time.

Key words: Heavy metals, soil, oil field, Niger Delta

*Corresponding Author, E-mail:maxipriestley@yahoo.com

\section{INTRODUCTION}

Contamination of heavy metals in the environment is of major concern because of their toxicity and threat to human life and the environment (Purves, 1995; Ma and Rao, 1997). Metal interaction in soil vary considerably with the nature of soil types. The phytoavailability of metals is determined by the nature of the metal species, their interaction with soil colloids, the soil characteristics and duration of contact with surface binding (Naidu et al., 2003). Soil characteristics (e.g. soil $\mathrm{pH}$, clay, organic matter content and types, and moisture content) also determine availability to plants by controlling the speciation of the elements, temporary binding by particles surface (adsorptiondesorption processes), precipitation reaction and availability in soil solution and he amount of moisture present in the soil (Fotovat et al., 1997; Naidu et al., 2003). Much research has been conducted on heavy metals contamination in soils from various anthropogenic sources such as industrial waste (Haine and Pocook, 1980; Parry et al., 1981; Culbard et al., 1983; Gibson and Farmer, 1983), automobile emission (Largerwerff and Specht, 1970; Furgusson et al., 1980 and Garcia-Miragaya, 1980), minning and smelting activities (Davies and Ginnever, 1979; Culbard and Johnson, 1984; Ma and Rao, 1997 and Kabala and Singh, 2001), agricultural practice (Culbard and Johnson, 1984), and urbanization (Lavado et al., 1998). From the foregoing, it is evident that considerable works have been done on the contamination of soil by anthropogenic sources in most developed countries. There is paucity of information from developing countries like Nigeria, and more so, relatively few studies have been reported on the heavy metals status of soils of some oilfield in the Niger Delta. The primary objectives of the present study were to investigate the characteristic levels of heavy metals and some physicochemical properties of soils from an oilfield in the Niger Delta.

\section{MATERIALS AND METHODS}

The study area lies between longitude $6^{\circ} 20^{1}$ to $6^{\circ}$ $50^{1} \mathrm{E}$ and latitude $5^{\circ} 20^{1}$ to $5^{\circ} 40^{1} \mathrm{~N}$. The area is located at the Northern part of the Niger Delta. This area is characterized with multiple oil wells, criss-crossing of 
surface and subsurface pipelines and multiple gas flare points. The area also houses three major gas plants and gas compression stations. Apart from peasant farming, the major industrial activity in this area is that of oil and gas exploration and exploitation.

\section{Sampling and analysis}

Soil samples were collected within $2 \mathrm{~km}$ x $2 \mathrm{~km}$ quadrant around the gas plant and within $20 \mathrm{~m}$ radius at designated interval along the existing oil pipelines. The quadrant was subdivided into 16 cells (125 m x $125 \mathrm{~m}$ ) with each denoting a sampling station. A composite sample consisting of at least six random samples were collected in each cell. A total of 32 sampling sites were examined. The soil samples were collected at $0-20 \mathrm{~cm}$ depths using a hand auger. All samples were air dried and ground to pass through 2 $\mathrm{mm}$ mesh. The samples were collected in two regimes (1) January - February, 2005 for dry season samples and June and July, 2005 for rainy season samples. The particle size distribution was determined by the hydrometer method for silt and clay and by dry saving for sand fraction (Reeuwijk, 1995). Soil pH was measure in $1^{`}: 2.5(\mathrm{v} / \mathrm{v})$ ratio of soil and water suspension (Reeuwijk, 1995). Cations exchange capacity was determined as a sum of basic cation extracted with neutral IM NH $\mathrm{NH}_{4} \mathrm{OAc}$ and the extractable acidity (Reeuwijk, 1995). Total organic carbon was determined by the wet dichromate method of Walkley and Black (Nelson and Sommer, 1985). Total trace metal content contents $(\mathrm{Cd}, \mathrm{Cr}, \mathrm{Cu}, \mathrm{Pb}, \mathrm{Ni}, \mathrm{Fe}$, and $\mathrm{Zn}$ ) were determined as aqua-ragia/HF extracted amount using air-acetylene flame atomic absorption spectrophotometer (AAS) (Perkin Elmer A3100). For analysis of vanadium, a nitrous-oxide flame was used. Mercury and arsenic was determined by cold vapour and hydride generation atomic absorption respectively after a specific destruction (Cottenie et al., 1982). The atomic absorption spectrophotometer was fitted with $\mathrm{D}_{2}$ background correction devices. Sample was analyzed in triplicate. Uncertainty is expressed as a percentage calculation on the basis of maximum standard deviation. The coefficients variation obtained were less than $5 \%$ for all metals.

\section{RESULTS}

Table 1 reports the particle size distribution and some general characteristics namely $\mathrm{pH}$, percentage organic carbon, cation exchange capacity (CEC), conductivity and moisture content of the examined soils. The $\mathrm{pH}$ is acid with mean $\mathrm{pH}$ values of 4.63 (3.51-6.83) and 5.00 (4.29-7.33) for wet season and dry season respectively. Analysis of variance ( $p>0.05)$ showed no significant spatial and temporal variation in the $\mathrm{pH}$ levels of the examined soils. The mean levels total organic carbon (TOC) were 1.83\% with range of 0.89 to $2.5 \%$ for wet season and $1.53 \%$ with range of 0.89 to $2.3 \%$. The cation capacity of soils ranged from 5.46 to 23.5 meq/100g with mean value of 13.31 and 0.39 to $9.2 \mathrm{meg} / 100 \mathrm{~g}$ with mean value of $3.99 \mathrm{meq} / 100 \mathrm{~g}$ for wet and dry season respectively. Also the moisture contents of examined soil ranged from 13.6 to $52.7 \%$ and $0.9 \%$ to $29.3 \%$ for wet and dry seasons respectively. Analysis of variance $(\mathrm{p}<0.05)$ showed significant spatial and temporal variations in the levels of total organic carbon, cation exchange capacity and moisture content of the examined soils. Sand fraction forms the predominant fraction in terms of particle size distribution. It ranged from $30 \%-100 \%$ in the soils. Whereas silt and clay fractions ranged from 0.00-45.8 and $0.00-30.0 \%$. Like other soil general characteristics there is significant spatial variation in the particle size distribution. Table 2 presents the mean concentrations, range of heavy metals in the investigated soils. The mean concentrations of cadmium were $0.68 \mathrm{mg} / \mathrm{kg}(0.22-1.73 \mathrm{mg} / \mathrm{kg})$ and 0.76 $\mathrm{mg} / \mathrm{kg}(0.02-1.60 \mathrm{mg} / \mathrm{kg})$ for wet season and dry seasons respectively. At $\mathrm{p}<0.05$ the concentrations of cadmium showed significant spatial variations. The concentrations of lead in all sites ranged from 2.00 to $15.00 \mathrm{mg} / \mathrm{kg}$ with mean levels of $6.53 \mathrm{mg} / \mathrm{kg}$ and 3.00 $58.00 \mathrm{mg} / \mathrm{kg}$ with mean levels $10.2 \mathrm{mg} / \mathrm{kg}$ for wet and dry seasons respectively. Like cadmium and lead, other metals showed significant spatial and temporal variations in the concentrations of these metals except for arsenic. Iron showed the highest concentration in all sites compared with other metals. Table 3 presents the mean concentrations, coefficient of variation and ranges of heavy metals in soil samples collected within the gas plant areas and those collected along the pipeline areas. Paired t-test $(\mathrm{p}<0.05)$ was used to compare the concentrations of heavy metals in soils from gas plant areas and pipeline area. The results revealed that gas plant areas have significant $(\mathrm{p}<0.05)$ higher concentrations of heavy metals compared to pipelines areas in for both wet and dry seasons. 
Preliminary assessment of...

Table 1: Some physicochemical properties of soils of an oilfield in the Niger Delta

\begin{tabular}{lllllll}
\hline \multicolumn{1}{c}{ Parameter } & \multicolumn{1}{c}{ Mean \pm S.D. } & $\begin{array}{c}\text { Wet season } \\
\text { range }\end{array}$ & \multicolumn{1}{c}{ CV $(\%)$} & Mean \pm S.D. & $\begin{array}{c}\text { Dry season } \\
\text { range }\end{array}$ & CV (\%) \\
\hline Sand (\%) & $63.78 \pm 26.16$ & $30.0-100$ & 41.0 & - & - & - \\
Silt (\%) & $24.59 \pm 16.58$ & $0.00-45.8$ & 67.4 & - & - & - \\
Clay (\%) & $11.67 \pm 10.71$ & $0.00-30.0$ & 91.8 & - & - & - \\
pH & $4.63 \pm 0.78$ & $3.51-6.83$ & 16.8 & $5.00 \pm 0.85$ & $4.29-7.33$ & 17.0 \\
Conductivity $\mu$ S/cm & $75.89 \pm 66.20$ & $28.7-309$ & 87.2 & $83.76 \pm 54.10$ & $31.0-276$ & 64.5 \\
TOC(\%) & $1.83 \pm 0.89$ & $0.89-2.5$ & 486 & $1.53 \pm 0.74$ & $0.89-2.30$ & 48.4 \\
CEC (Meq/100g) & $13.31 \pm 5.16$ & $5.46-23.5$ & 38.8 & $3.99 \pm 3.44$ & $0.39-9.20$ & 86.2 \\
Moisture (\%) & $26.82 \pm 9.17$ & $13.6-52.7$ & 34.2 & $12.87 \pm 8.38$ & $0.90-29.3$ & 65.1 \\
\hline
\end{tabular}

TOC = Total organic carbon; $\mathrm{CEC}=$ cation exchange capacity; $\mathrm{SD}=$ standard deviation; $\mathrm{CV}=$ coefficient of variation

Table 2: Total metals concentration of soils of an oilfield in the Niger Delta, typical range and most common values, average abudance in the earth crust (values in $\mathrm{mg} / \mathrm{kg}$ unless otherwise stated)

\begin{tabular}{|c|c|c|c|c|c|c|c|c|}
\hline Metal & Mean \pm S.D. & $\begin{array}{l}\text { Wet season } \\
\text { range }\end{array}$ & $\begin{array}{l}\mathrm{CV} \\
(\%)\end{array}$ & Mean \pm S.D. & $\begin{array}{l}\text { Dry season } \\
\text { range }\end{array}$ & $\begin{array}{l}\mathrm{CV} \\
(\%)\end{array}$ & $\begin{array}{l}\text { Typical } \\
\text { range }\end{array}$ & $\begin{array}{c}\text { Common } \\
\text { value }\end{array}$ \\
\hline $\mathrm{Cd}$ & $0.68 \pm 0.51$ & $0.02-1.73$ & 75 & $0.76 \pm 0.43$ & $0.02-1.60$ & 56.7 & $0.01-2.0$ & $0.1-1$ \\
\hline $\mathrm{Pb}$ & $6.53 \pm 3.53$ & $2.00-15.00$ & 54.1 & $10.2 \pm 10.6$ & $3.0-58.0$ & 103.9 & $2-300$ & $10-30$ \\
\hline $\mathrm{Cu}$ & $6.33 \pm 4.38$ & $0.05-19.00$ & 69.2 & $7.09 \pm 4.58$ & $1.00-97.5$ & 67.7 & $2-250$ & $20-30$ \\
\hline $\mathrm{Cr}$ & $15.74 \pm 7.50$ & $4.00-35.00$ & 47.6 & $11.70 \pm 11.30$ & $1.00-62.0$ & 76.9 & $3-1500$ & $70-100$ \\
\hline $\mathrm{Ni}$ & $4.43 \pm 3.26$ & $0.10-12.00$ & 73.6 & $5.73 \pm 2.38$ & $1.50-10.0$ & 41.5 & $2-750$ & 50 \\
\hline $\mathrm{Fe}$ & $\begin{array}{l}55595.97 \pm \\
33410.92\end{array}$ & $36186-108,054$ & 60.0 & $\begin{array}{l}15109.16 \\
\pm 11081.83\end{array}$ & $481-46,431$ & 73.3 & $\begin{array}{l}7000- \\
42,000\end{array}$ & - \\
\hline Mn & $183.61 \pm 113.30$ & $13.0-364$ & 61.7 & $\begin{array}{l}247.38 \pm \\
158.57\end{array}$ & $7.00-623.0$ & 64.1 & $20-10,000$ & 1000 \\
\hline $\mathrm{Zn}$ & $32.41 \pm 19.41$ & $4.00-73.0$ & 59.9 & $21.41 \pm 15.98$ & $4.00-61.0$ & 74.6 & $1-90$ & 50 \\
\hline V & $24.05 \pm 17.27$ & $0.20-58.0$ & 74.2 & $21.35 \pm 14.91$ & $<0.20-55.0$ & 69.8 & - & - \\
\hline$* *$ As & $0.0005 \pm 0.000$ & $0.0005-<0.001$ & 0.0 & - & - & - & - & \\
\hline$* * \mathrm{Hg}$ & $0.38 \pm 0.32$ & $0.02-2.55$ & 84.2 & - & - & - & - & - \\
\hline
\end{tabular}

\section{DISCUSSION AND CONCLUSION}

In general, the soils have a low clay content and organic matter, so they tend to be permeable. The soils have also low CEC. The CEC found in this study is similar values reported for Rivers State swamp soil (Isirimah, 1987). The $\mathrm{pH}$ of the soils of the oilfield is acidic, such acidic characteristics is typical of the Niger Delta soils (Isirimah, 1987 and Odu et al., 1985). Several studies have shown that increased availability of many of these metals with decreasing $\mathrm{pH}$ (Itanna, 1998). The $\mathrm{pH}$ values of the soil examined also indicate a generally high tendency of high availability of these metals. Hence, this is a favorable natural mechanism increasing risk of at least plant uptake. The effect of $\mathrm{pH}$ value $<6$ in increasing metal ion activities in soil can be attributed to the decrease in $\mathrm{pH}$-dependent surface charge on oxides $\mathrm{Fe}, \mathrm{Al}$ and $\mathrm{Mn}$, chelation by organics of metal hydroxide (Adriano et al., 2002). Table 2 presents the mean concentrations, range of heavy metals in the investigated soils and, for comparism, their typical concentration ranges in soils (Alloway, 1990). The examined soils can be considered unpolluted, since the concentrations of metals fit into typical range and concentrations found in agricultural soils (Kabata-Pendias and Pendias, 1992) with exception of cadmium and lead in some sites. This suggests that heavy metal contents in the soils of the oilfield are not largely affected by human activities. The examined soils showed spatial variation in the concentrations of metals in the examined soils. The spatial variation is probably due to differences in moisture content, clay content, cation exchange capacity, organic matter content and $\mathrm{pH}$ of the different sites. Arsenic showed no significant spatial and temporal variation in concentration. The concentration of arsenic in all soils examined was less than $0.005 \mu \mathrm{g} / \mathrm{g}$. The results indicate that concentrations of these metals were higher in the dry season except for chromium, zinc, and vanadium. The seasonal variations in the concentrations of the metals could be attributed to differences in individual metal solubility, $\mathrm{pH}$ and leaching by acidic rain during the wet season. 
C. M. A. Iwegbue, et al.

Table 3: Mean concentration of heavy metals (mg/kg), range of soils around the Gas plant and pipeline Areas Gas plant Area

\begin{tabular}{|c|c|c|c|c|c|c|}
\hline Metal & Mean \pm S.D. & $\begin{array}{c}\text { Wet season } \\
\text { Range }\end{array}$ & CV. (\%) & Mean \pm S.D. & $\begin{array}{c}\text { Dry season } \\
\text { Range }\end{array}$ & CV (\%) \\
\hline $\mathrm{Cd}$ & $0.84 \pm 0.61$ & $0.05-1.73$ & $51 \%$ & $0.96 \pm 0.47$ & $0.41-1.60$ & 48 \\
\hline $\mathrm{Pb}$ & $7.44 \pm 2.94$ & $4.00-13.0$ & 39.5 & $13.30 \pm 13.80$ & $4.00-58.0$ & 103.8 \\
\hline $\mathrm{Cu}$ & $7.78 \pm 4.02$ & $3.00-17.0$ & 51.7 & $8.00 \pm 3.90$ & $3.00-16.0$ & 48.8 \\
\hline $\mathrm{Cr}$ & $17.78 \pm 6.06$ & $11.0-35.0$ & 34.1 & $19.00 \pm 12.90$ & $7.00-62.0$ & 67.9 \\
\hline $\mathrm{Ni}$ & $4.81 \pm 2.20$ & $2.0-10.0$ & 45.7 & $6.13 \pm 2.28$ & $3.00-10.0$ & 37.2 \\
\hline $\mathrm{Fe}$ & $61625.88 \pm 12447.82$ & $36,186-108,059$ & 31.6 & $15653.88 \pm 10613.24$ & $1385.0-37,480$ & 67.8 \\
\hline Mn & $199.56 \pm 115.36$ & $50.0-506.0$ & 57.8 & $237.19 \pm 160.07$ & $52.0-623$ & 67.5 \\
\hline $\mathrm{Zn}$ & $38.13 \pm 17.30$ & $19.0-73.0$ & 45.4 & $23.06 \pm 13.67$ & $10.0-56.0$ & 59.3 \\
\hline $\mathrm{V}$ & $28.19 \pm 14.16$ & $11.0-69.0$ & 50.2 & $25.08 \pm 15.00$ & $0.20-49.0$ & 59.8 \\
\hline As ** & $0.0005 \pm 0.000$ & $0.0015-0.001$ & - & - & - & - \\
\hline $\mathrm{Hg} *$ & $\begin{array}{l}0.32 \pm 0.08 \\
\text { Along pipelines }\end{array}$ & $0.06-0.41$ & 25.8 & - & - & - \\
\hline $\mathrm{Cd}$ & $0.52 \pm 0.48$ & $0.02-0.88$ & 92.3 & $0.61 \pm 0.39$ & $0.02-0.97$ & 63.9 \\
\hline $\mathrm{Pb}$ & $5.67 \pm 3.91$ & $1.00-15.0$ & 69.0 & $7.13 \pm 4.54$ & $3.00-20.0$ & 63.4 \\
\hline $\mathrm{Cu}$ & $4.88 \pm 4.36$ & $0.05-13.0$ & 89.3 & $6.63 \pm 7.00$ & $1.00-29.0$ & 105.6 \\
\hline $\mathrm{Cr}$ & $13.69 \pm 8.40$ & $4.00-27.0$ & 61.4 & $9.76 \pm 7.20$ & $1.00-23.0$ & 73.8 \\
\hline $\mathrm{Ni}$ & $404 \pm 410$ & $0.10-12.0$ & 101.5 & $5.34 \pm 2.49$ & $1.50-9.00$ & 46.6 \\
\hline $\mathrm{Fe}$ & $49566.06 \pm 33556.17$ & $8,862-115,229$ & 67.7 & $13380.00 \pm 12322.41$ & $481.0-46.430$ & 92.1 \\
\hline $\mathrm{Mn}$ & $167.66 \pm 112.61$ & $31.0-357.0$ & 67.2 & $257.56 \pm 161.61$ & $7.00-544.0$ & 62.7 \\
\hline $\mathrm{Zn}$ & $26.69 \pm 20.94$ & $4.00-57.0$ & 78.5 & $19.75 \pm 18.30$ & $4.00-61.0$ & 92.7 \\
\hline V & $19.91 \pm 19.48$ & $0.20-58.0$ & 97.8 & $18.95 \pm 14.54$ & $0.20-55.0$ & 76.7 \\
\hline As & $0.02 \pm 0.06$ & $<0.0001-0.21$ & 0.0 & - & - & - \\
\hline $\mathrm{Hg} *$ & $0.43 \pm 0.57$ & $0.02-2.55$ & 134.5 & - & - & - \\
\hline
\end{tabular}

${ }^{*} \mu \mathrm{g} / \mathrm{kg}$ mean computed based on half of detection limit

Table 3 Soils around the gas plant showed significantly higher mean levels of these metals in all seasons compared to those collected along the pipeline areas. The high concentrations of metals in the around the gas plant area reflect an anthropogenic input, since exogenous metals are usually more weakly bound to the soil matrix, therefore are more readily released ( $\mathrm{Li}$ et al., 1995 and Abollino et al., 2002). There is more build up of metals in the gas plant area than along existing pipelines, obviously because the heavy metal build up is a gradual process and hence farmlands and fish ponds closer to these facilities will be also risk of heavy metal pollution overtime. The following metals $\mathrm{V}, \mathrm{Ni}, \mathrm{Cr}, \mathrm{Fe}$, $\mathrm{Pb}, \mathrm{Cu}$ and $\mathrm{Zn}$ showed significant positive correlation with cation exchange capacity. This correlation suggested that non-specific adsorption process controls metal adsorption and the adsorption capacity of the soil is dictated by the cation exchange capacity. However, in many soils the amount of metals sorbed exceeds the cation exchange capacity of the soils. This infers that in addition to non-specific adsorption/other processes such as specific adsorption, precipitation and complex formation also contribute to the retention of metals (Adraino et al., 2002). The correlation between the following metals $\mathrm{Pb}, \mathrm{Cu}, \mathrm{Cr}, \mathrm{Ni}, \mathrm{Fe}, \mathrm{Mn}, \mathrm{Zn}$, and $\mathrm{V}$ cannot be explained in terms of chemical properties, origin or biological function. While clay cation exchange capacity and organic carbon content may be the major factors in determining the retention of trace metal that mainly occur in cationic forms (eg $\mathrm{Zn}, \mathrm{Cu}$, Pb etc.), the more complex environmental chemistry of Hg implies that several mechanism may significantly control $\mathrm{Hg}$ retention. For example, the retention of $\mathrm{Hg}$ in soil is not only cause by valence-type adsorption by organic and inorganic materials. It may be retained by formation of covalent bonds with organic compounds or by precipitation as highly insoluble carbonates, phosphates and sulphides (Adraino, 1986; Yaron et al., 1996 and Tack et al., 1997). Mercury is present naturally in soils at concentration from a few $\mu \mathrm{g} / \mathrm{kg}$ to several hundred $\mu \mathrm{g} / \mathrm{kg}$ (Adraino, 1986). While concentration and median values were in order of 100 $\mu \mathrm{g} / \mathrm{kg}$, value up to $2.26 \mu \mathrm{g} / \mathrm{kg}$ were considered representative for current $\mathrm{Hg}$ in common Flemish soils (Tack et al., 1997). The concerntration of mercury we found in our study is lower than this range. Will and Suter (1995) derived a benchmark Cu concentration of $100 \mathrm{mg} / \mathrm{kg}$ for the protection of terrestrial plants, 
incidence of phytotoxicity has been recorded at concentrations in the order of $100 \mathrm{mg} / \mathrm{kg}$ in the Australian environment. Olzowy et al., (1993) observed maximum Cu concentration of $466 \mathrm{mg} / \mathrm{kg}$ soil with $95^{\text {th. }}$. percentile of $122 \mathrm{mg} / \mathrm{kg}$ in Australian urban soils but found no incidence of phytotoxicity at these site. Similarly, Merry et al., (1983) reported Cu concentrations in Australian orchard soils of 11-320 with an average value exceeding $100 \mathrm{mg} / \mathrm{kg}$. The concentration of copper found in this study was far below levels reported by these researchers. The concentration of $\mathrm{Pb}, \mathrm{Cr}, \mathrm{Cd}, \mathrm{Cu}, \mathrm{Ni}$ and $\mathrm{Zn}$ we found in our study were far below levels reported for agricultural soils from Piedmont, Italy (Abillono et al., 2002), contaminated sites in U.S.A (Ma and Rao, 1997) and soils from Baia Mare region, North West side of Romania (Mihaly-Cozmuta et al., 2005). However the concentrations of the metals recorded in this study fit into the range reported by Tack et al., (1997). Osuji and Onojake (2004) reported mean levels ranging from 12.6 $\mathrm{mg} / \mathrm{kg}-12.8 \mathrm{mg} / \mathrm{kgNi}, 4.1 \mathrm{mg} / \mathrm{kg}-5.2 \mathrm{mg} / \mathrm{kg} \mathrm{Cu}, 10.0-$ $10.8 \mathrm{mg} / \mathrm{kg} \mathrm{Pb},<0.2 \mathrm{mg} / \mathrm{kg} \mathrm{V}$ and $<0.2 \mathrm{mg} / \mathrm{kg} \mathrm{Cd}$ for subsoil to topsoil respectively for soil samples collected 6 months after the Ebocha - 8 oil spillage in the Niger Delta, Nigeria. The levels we found in our study are comparable to thelevels reported by these authors except for vanadium and cadmium. Arsenic is widely distributed in soils and with average concentrations in the range of $1-40 / \mathrm{mg}$, with a mean value of approximately $5 \mathrm{mg} / \mathrm{kg}$ (Yan Chu, 1994). Arsenic content range between $<5$ and $175 \mathrm{mg} / \mathrm{kg}$ with a median value of $8 \mathrm{mg} / \mathrm{kg}$ have reported for Swedish tills. Tack et al., (1997) reported as concentrations in the range of 0.82 $-95 \mathrm{mg} / \mathrm{kg}$ with a median value of $7.0 \mathrm{mg} / \mathrm{kg}$ in Flemish rural soil. Bhattacharya et al., (2002) reported high concentration of arsenic varying between $10 \mathrm{mg} / \mathrm{kg}$ and as high as $1067 \mathrm{mg} / \mathrm{kg}$ in mineral soils of contaminated sites at Konsterund, Kristineharmm Community, Central Sweden. The concentration of as we found in this study were far below those range. The concentration of Arsenic all sites mere below the limits of analytical detection except for two sites that have arsenic concentrations of $0.14 \mathrm{mg} / \mathrm{kg}$ and $0.21 \mathrm{mg} / \mathrm{kg}$. Since characteristic levels of heavy metals recorded in our study fitted into concentrations found in natural and unpolluted soils. The soils collected around these facilities are considered unpolluted and are not largely influenced by human activities. However, it is evident that there is a gradual build up of heavy metals in the soil around the gas plant area compared to soil collection along the transport pipelines. This reflect intense anthropogenic activities around the gas plant areas. The distribution pattern of these heavy metals were in the following other $\mathrm{Fe}>\mathrm{Mn}>\mathrm{Zn}>\mathrm{V}>\mathrm{Cr}>\mathrm{Pb}$ $>\mathrm{Cu}>\mathrm{Ni}>\mathrm{Cd}>\mathrm{Hg}>$ As. Non specific adsorption process form the major control mechanism for metal adsorption in these soil and the adsorption capacity of the soil is controlled by cation exchange capacity. Metal build up is gradual process, constant monitoring of the levels of these metals is required to safeguard farmlands, fish pound and water bodies around these facilities.

\section{REFERENCES}

Abollino, O., Acato, M., Malandrino, M., Menstasti, E., Sarzanini, C. and Petrella, F., (2002). Heavy metals in agricultural soils from piedmont, Italy. Distribution, speciation and chemometric data treatment. Chemosphere, 49, 545-557.

Adriano, D. C., (1986). Heavy metal metals in the environment Springer-Verlag, New York.

Adriano, D. C., Bolan, N. S., Koon, B. J., Naidu, R., Lelie, D., Vangronsveld, J. and Wenzel, W.W., (2002),.Natural remediation processes bioavailability interactions in contaminated soils $17^{\text {th. }}$ WCSS Symposium 14-21 August 2002, Thailand, 42, 501.

Alloway, B. J., (1990). The origins of heavy metals in soil. In Aloway B. J. (Ed.), Heavy metals in soil. Blackie, Glasgow and London, 29-39.

Cottenie, A., Verloo, M., Kieken, E., Velghe, G. and Camerlynk, R., (1982). Chemical analysis of plant and soil IWONL, Brussel.

Culbard, E. B. and Johnson, L. R., (1984). An assessment of Arsenic in house dust and garden soils from south west England and their implications for human health, In Environmental contamination CEP, Edinburgh, 276-281.

Fergusson, J. E., Hayes, R. W., Tan, S. Y. and Sim, H. J., (1980). Heavy metals pollution by traffic in Christ Church, New Zealand lead and cadmium content of dust, soil and plant samples. N. Z. J. Sci., 23, 293-310.

Foto vat, A., Naidu, R. and Suer, M. E., (1997). Water: soil ratio influences aqueous phase chemistry of indigenous copper and Zinc in soils. Aust. J. Soil Res., 35, 687-710.

Garcia-Miragaya, J., (1984). levels; chemical fractions and solubility of lead in roadside soils of Caracas. Venezuela. Soil Sci., 138, 147-152.

Haines, R. C. and Pocock, R. L., (1980). Heavy metal land contamination: Background levels and site case histories in London Borough of Greenwich. Res. Note 16 Birmingham, Joint unit for Research on the Urban Environment. Univ. of Aston, Birmingham.

Isirimah, N. O., (1987). An Inventory of some chemical properties of selected surface soils of River state of Nigeria: In proceedig of $15^{\text {th. }}$ annual conference of Soil Science Association of Nigeria. Kaduna, 217-233. 
Itanna, F., (1998). Comparative study on soil pollution with toxic substances on farmlands close to old and New Industrial sites in Ethiopia. Bull. Chem. Soc. Ethiop., 12 (2), 105112.

Kabala, C. and Singh, B. R., (2001). Fractionation and Mobility of copper, lead, and zinc in soil profiles in the vicinity of a copper smelter. J. Environ. Qual., 30, 485-492.

Kabata-Pendias, A. and Pendias, (1992). Trace elements in soil and plants. $2^{\text {nd. }}$ ed CRC Press, Boca Raton, FL.

Largerweff, J. V. and Specht A. W., (1970). contamination of Roadside soils and vegetation with cadmium, nickel, lead and zinc. Environ. Sci., 4, 583-586.

Lavado, R. S., Rodriguez, M. B., Scheiner, J. D., Taboada, M. A., Rubio, G., Alvarec, R., Akonada, M. and Zubillaga, M. S., (1998). Comm. Soil Sci. Plant Anal., 29, (11-14) 19131917.

Li, X., Coles, B. J., Ramsey, M. H. and Thornton, I., (1995). Chemical partitioning of the new National Institute of standard and Technology standard reference materials (SRM 2709-2711) by sequential chemical extraction using inductively coupled plasma atomic emission spectrometry. Analyst 120, 1415-1419.

Lund, W., (1990). Speciation analysis-why and how? Fresenius J. Anal. Chem., 337, 557-564.

Ma, L. Q, and Rao, G. N., (1997). Chemical fractionation of cadmium, Nickel, and Zinc in contaminated soils Journal of Environ. Qual., 26, 259-264.

Merry, R. H., Tiller, K. G., and Alston, A. M., (1983). Accumulation of copper, lead and arsenic in some Australian orchard soil. Aust. J. Soil Res., 21, 549-561.

Mihaly-Cozmuta, A., Mihaly-Cozmuta, L., Viman, V., Vatea, G. and Varga, C., (2005). Spectrophotometeric methods used to Determine heavy metal pollution and total cyanides in accidental polluted soils. Am. J. Appl. Sci., 2 (1), 358-362.

Naidu, R., Oliver, D. and McConnell, S., (2003). Heavy metal phytotoxicity in soils. In Langley A., Gilbey M. and Kennedy B (Eds.), proceedings of the fifth National workshop on the
Assessment of site contamination National Environment Protection Council service corporation Adelaide S. A.

Nelson, D. W., and Sommer, G. E. (1986). Total carbon, organic carbon and organic matter: In Page AL, Miller R.H. Kenney D.R. (Eds.). Method of soil analysis. Part 2 chemical and microbiological properties. Agronomy series 9. $2^{\text {nd. }}$ ed. American society of Agronomy, Madison, Wisconsin, 539579.

Olszowy, H., Torr, P., Imray, P., Smith, P., Hegarty, I. and Hastie, G., (1993). Report on studies of levels of trace elements in soil from Rural and Urban Areas of Australia. Contaminated sites monograph No. 4, Department of Human services and Health Environmental Protection Agency and South Australian Health commission.

Osuji, L. C. and Onojake, C. M., (2004). The Ebocha - 8oil spillage II. Fate of associated heavy metals six months after. African J. Environ. Assess. Moni., 9, 78-87.

Purves, D., (1985). Trace-element contamination of the environment Elsevier, Amsterdam.

Reeuwijk, L. P., (1995). Procedure for soil Analysis Technical paper $9.5^{\text {th }}$ Ed. ISRIC, Wageningen, The Netherlands.

Tack, F. M. G., Verloo, M. G., Vanmechelen, L. and Van Eanst, E., (1997). Baseline concentration levels of trace elements as a function of clay and organic carbon contents in soils in Flanders (Belgium). Sci. Total Environ., 201, 113-123.

Will and Suter, (1995). cited in (2003) Proceeding of the fifth National workshop on the assessment of site contamination. National environment protection council service corporation, Adelaide S.A.

Yan Chu, H., (1994). Arsenic distribution in soils. In Nriagu J. O. (ed.) Arsenic in the environment, Part I, Cycling and Characteristics, John Wiley, 17-49.

Yaron, B., Calvet, R., Prost, R., (1996). Soil pollution: processes and dynamics, Springer-Verlag; Berlin.

\section{AUTHOR(S) BIOSKETCHES}

Iwegbue, C. M. A., Department of Chemistry, Delta State University, Abraka, Nigeria.

E-mail:maxipriestley@yahoo.com

Egobueze, F. E., Institute of Geosciences and Space Technology, Rivers State University of Science and Technology, Port Harcourt, Nigeria. E-mail: femexie@yahoo.com

Opuene, K., Department of Chemistry, University of Nigeria, Nsukka, Nigeria.

E-mail:opuenkings@yahoo.com

This article should be referenced as follows:

Iwegbue, C. M. A., Egobueze, F. E. and Opuene, K., (2006). Preliminary assessment of heavy metals levels of soils of an oil field in the Niger Delta, Nigeria. Int. J. Environ. Sci. Tech., 3 (2), 167-172. 